\title{
EXEMPTION OF CHURCHES AND CHARITABLE INSTITUTIONS FROM ASSESSMENTS FOR STREET PAVING, ETC.
}

The Supreme Court of Pennsylvania in the case of the Appeal of the M. E. Clutrch of Sereickley', 35 IV. N. C. 554, decided in January, I895, has overruled its own most recent decisions on the subject, and has gone entirely contrary to the popular and professional understanding. The appellant had been assessed for the paving of a street in front of its church building, the paving having been ordered by the borough authorities in response to a petition in which the appellant had joined. The court below, on what grounds the report of the case does not state, upheld the assessment. The Supreme Court affirms the judgment upon two grounds; first, that having joined in the petition for the paving, the church was bound in equity and good conscience to pay its share of the cost: and second, that " taxation," from which churches wereexempted by the Act of May 14, I874, did not include within its meaning special charges of this character, but included only general burdens, borne by the people at large. The opinion is delivered by Chief Justice STERRETT, and there is not a dissenting voice, although the concluding paragraph expressly overrules all former decisions inconsistent with the present ruling. Perhaps, however, the most important feature of the opinion is the strong intimation, that even had the Act of 1874 included such charges in express terms, it would have made no difference, as such a provision would exceed the constitutional power of the legislature, as the authority to exempt from taxation was derived from the constitution, and, as before stated, the word " taxation" did not include local assessments for municipal improvements. Chief Justice SterRetr cites two cases in the earlier Pennsylvania reports: Northem Liberties v. St. John's Church, I 3 Pa. I04, and Pray v. Northern Liberties, 3I Id. 69. But he relies on Illinois Central $R$. R. v. Decatur, I47 U. S. 190, 197. He recognizes 
the fact that local assessments are " referable to the taxing power," but says that the distinction drawn between them and general taxes in questions of exemption is well recognized, and supported by "an almost unbroken line of authorities in nearly all of our Eastern States." The effect of this decision is very serious; and it is proposed herein to consider the subject as fully as space will permit; necessarily it will have to be considered somewhat from a Pennsylvania standpoint. But the question, and the public policy involved in it, are much the same everywhere. First, then, as to the law of Pennsylvania, as it stood prior to this decision. The case of Pray v, Northern Liberties, though reported later, was decided prior to Northern Liberties against St. John's Church, in which it is mentioned. It was not a question of the exemption of charitable institutions from taxation at all, but was an effort on the part of an individual to escape payment of municipal assessment on the ground that the amount due had not been registered ni the office of the county commissioners, in obedience to the Act of 1824 , requiring all zinpaid taxes to be so registered. The court simply decided squarely that such an assessment was not a tax. And when the question came up in Northern Liberties v. St. John's Church, supra, Judge Coulter, who had delivered the opinion in the former case, referred to the fact that it had already been decided that such assessments were not taxes, and added that it was evident on the face of all the Acts relating to them in corporated districts, that the legislature had the distinction in mind. In Pennock v. Hoover, 5 Rawle, 291, decided fifteen years earlier, it had been distinctly held that such assessments were taxes, under the very Act of 1824 , above referred to, and as such were a lien prior to those of mechanics. In Borough of Greensburg v. Young, 53 Pa. 280 , such assessments were stated by Judge Thompson, not to be taxes, citing the two Northern Liberties cases, but the point before him was as to whether if their collection would exceed the amount the borough was permitted to raise by taxation in any one year, they could not be imposed. The decision was no doubt entirely correct-such could hardly have been the intention of the legislature. 
Subsequent cases, among which may be mentioned, Washington Ave., $69 \mathrm{~Pa} .352$, and Centre St., 1 I $5 \mathrm{~Pa}$. 253, say that such assessments can only be sustained under the power to tax. Judge Agnew, in Washington Avenue, just cited, remarked that if Pray' v. The Northern Liberties and the other two cases, had meant that such assessments were not taxation at all, it would in effect deny the power of the legislature to authorize the assessments. Equally emphatic is the language of the late Judge Sharswood in Hammett v. Cily of Philadelphia, $65 \mathrm{~Pa}$. 146. But the very question was squarely decided in Olive Cemetery Co. v. Philadelphia, 93 Pa. 129; Erie v. Church, 105 Pa. 280, and Philadelphia v. Church, I $34 \mathrm{~Pa} .207$, in all of which the respective institutions were held to be exempt.

In Olive Cemetery v. Phila., the court remarks : "If it were at all necessary, it would be an easy task to show the wisdom and propriety of exempting such property as that of the defendant in error from local taxation, but nothing of that kind is required. It is sufficient to know that the legislature, in creating the corporation, exempted its property from such taxation." Counsel in this case had called the attention of the court to some of the cases in New York, wherein a different rule had been laid down. This case was decided in 1880. Four years later came the case of Erie v. the Church. Here, again, many cases in other states were cited by counsel, and the court was asked to depart from Olive Cemetery v. Phila., and bring its rulings into agreement with those in other states. But this the court declined to do, saying, that the last mentioned case had definitely settled that such an assessment was a tax, and that, therefore, the church was exempt. In 1890 , the case of Phila. v. the Church was decided, and in a short per curiam opinion the exemption from such taxation was affirmed. In Phila. v. Penna. Hospital, I43 Pa. I67, it was held that the obligation to curb and pave footways was a police regulation, while the other assessments were taxes, and, therefore, the one could be enforced and the other could not: This case was simply an affirmance of Wilkinsburg $\mathrm{v}$. Home for Aged Women, I3 I Pa. Iog, decided in 1889. 
The late Chief Justice, who delivered the opinion of the court in that case, said in concluding: "We regret for the sake of this deserving charity that we are unable to reach a different conclusion. The law is too plain, however, to admit of even a doubt."

Prior to the adoption of the present constitution of 1874 , it had been definitely decided that such assessments were a tax. That constitution (Art. ix) provides that " the general assembly may, by general laws, exempt from taxation public property and for public purposes, actual places of religious worship," etc., etc. It does not specify the kind of taxes from which such institutions may be freed, but simply that that the legislature may exempt them from "taxation." By Act of May 14, 1874, such institutions are exempted "from all and every county, city, borough, bounty, road, school and poor tax."

To the average mind, it would seem difficult to imagine a more positive and comprehensive enactment. And, fortified as it has been by the language of the Supreme Court in the cases already cited, counsel who advised a client that an assessment of this kind was not a tax, or was not included in the meaning of the words of the constitution and Act of 1874 , would have been bold, indeed. More especially is this true, as the trend of decisions has been to widen the scope of this Act in other ways, and bring within its terms institutions, which certainly could have been excluded without doing violence to its words, and to hold certain "revenue and income" admittedly received by certain institutions as not within the meaning of those words in the Act. So that we are brought face to face with a practical repeal of a portion of the statute, or the reading into it of an exception not only not found in it expressly or impliedly, but which had been distinctly declared not to exist. The decision cannot but be regarded as an abrupt and startling departure from the declared and well-settled policy of the Commonwealth ; and it is to be presumed that the court felt moved to this by grave considerations of expediency; they say that they consider their present ruling sound in principle, and what they seem now to consider important, consonant with 
the rulings of other states. Now, let us examine some of the rulings elsewhere, beginning with $R . R$. Co. v. Decatur, I47 U.S. 190, 197, relied on by the court. The statute under consideration in that case was the Act of February 10, I85 I, of the Illinois legislature, incorporating the Railroad Company. By its 22d section, it declares: "The land selected [by the company] . . . shall be exempt from all taxation under the laws of this state.... After the expiration of six years ... an annual tax for state purposes shall be assessed by the auditor upon all the property . . . belonging to said corporation. Whenever the taxes levied shall exceed . . . such excess shall be deducted ... and the said corporation is hereby exempted from all taxation of every kind, except as herein provided for," etc., etc. The company was assessed for street paving in front of some of its land. Mr. Justice Brewer, in a long opinion, defends the distinction between general taxation and local assessments as sound in principle.

Space forbids an argument upon this point here. But in the course of his opinion, he says: "But it is said that it is with:n the competency of the legislature, having full control over the matter of general taxation and special assessments, to exempt any particular property from the burden of both, and that it is not the province of the courts, when such entire exemption has been made, to attempt to limit or qualify it upen their own ideas of natural practice." After citing numerous authorities, among them Olive Cemetery Co. v. Philadelphia and Erie v. Church, supra, he says: "This is undoubtedly true," and then turns to the statute in hand, to apply the test. Ard as it certainly would seem evident from that act that it contemplated only general taxation, the decision cannot be complained of. There was no question of a charity involved. The whole question of policy and the surrounding circumstances were entirely different. The case was an affirmance of the judgment of the Supreme Court of Illinois, and the Supreme Court of that State had held in several cases of which City of Chicago v. Lamed, 34 Ill. 203, is an example, that such assessments were not taxes, but were an exercise of the power of eminent domain, an additional reason: 
for construing the Act in question as not referring to them.

In the case of Harvard College v. Boston, 104 Mass. 470, where the words used in the college charter were "all civil impositions, taxes and rates," the words were held to include such assessments. In the course of its opinion, the court says, "it (the assessment) is in its legal character a tax, for it is levied, and can only be levied under the power of taxation confided by the constitution to the legislature." And after citing a case in Rhode Island as an example of cases, to be found elsewhere, they remark that the principle therein enunciated that such assessments "are both in the theory of the law and, in fact, but a return of a portion of the benefit specially conferred by the improvement," and that "provisions for exemption from taxes or impositions, whether existing in general statute laws or in special charters, are not to be deemed to include assessments for the improvement primarily of certain special localities, and derived from and carved out of the benefit conferred upon these special localities by these improvements" does not meet with their concurrence.

In Boston Seamen's Friend v. Mayor and Aldermen, I 16 Mass. I8I, it was held that such assejssments were not within the meaning of the exemption in the General Statute Tax Act of Massachusetts (Ch. I I $5, \S 5$, Ch. 37).

That Act provides a general tax law of the state, and section five-simply says: "The following property and polls shall be exempt from taxation," and then follows an enumeration. In Mt. Aubum Cemetery v. The Mayor and Aldermen, I 50 Mass. I2, the charter of the cemetery provided that its land should be exempted from "all public taxes." It was held that such assessments could not be collected-that it was not the intention of the legislature that they should beand that the decision, in I 6 Mass., supra, was under a general law, and there was an implied limitation of the restriction to taxes, which were the subject of the chapter.

In Brightman v. Kirner, 22 Wis. 54, the words in the Act of 1854 were, "which amount of tax shall take the place and be in full of all taxes of every name and kind 
upon said roads, or other properties belonging to said companies, or the stock held by individuals therein, and it shall not be lawful to levy or assess thereupon any other or further assessment or tax for any purpose whatever." In spite of the fact that the city of Milwaukee, by its charter granted in 1852 , had the power given it in express terms, to assess real estate exempted from taxation under the law of the state, it was held that the legislature had poiver to pass the Act of 1854 , and that its meaning was clear, and the assessments could not be levied.

In The People v. Trustees of School, i 8 Ill. 52, following Chicago v. The People, held school property exempt from assessments, as well as general taxation, even though there was no statute exempting it, on the ground that the Act of Congress enabling the people of Illinois to form a State Constitution, provided that "the section, numbered 16 , in every township ... shall be granted to the state for the use of the inhabitants of such township, for the use of schools," and Art. 8, § 2, Const. Ill., I 870, provides that "all lands, moneys or sther property donated, granted, or received for school, college, seminary or university purposes, and the proceeds thereof shall be faithfully applied to the objects for which such gifts or grants were made." At first blush, it is not easy to see just why, under these provisions, schools are exempt at all; but the court says that the reason is "the use for which the property "was granted," and that the above provision of the constitution prohibited the legislature from directly appropriating this property to state or municipal purposes, and it could not do so by the indirect means of taxation. Counsel had made the usual argument that assessments took nothing from the property, and the assessment is only the - extent of the benefit conferred upon it by the improvement. The court replies: "This may be so in theory, but not in certainty," and "it should not be exposed to the danger of being improved away, by being made to pay for supposed benefits conferred upon it by improvements." Why in the name of reason this answer could not be made in other cases, it is difficult to see, and yet this same court, in 
County of Adans v. Quincy, I30 Ill. 566, 574, quotes with approval an opinion sustaining an assessment against a cemetery company in the face of a statute exempting it from "any tax or public imposition whatever!"

In R.R. v. St. Paul, 2 I Minn. 526, it was held that "all taxation and assessment whatever," including municipal assessments. See, also, St. Paul v. R. R., 23 Minn. 469. So as to "all public taxes and assessments:" State v. City of. St. Paul, 36 Minn. 529. This was the case of a cemetery, and the court remarks that the object is not only to aid the cemetery in dollars and cents, "but mainly to preserve. cemeteries for the particular use to which they have been appropriated, and then in accordance with the common sentiments of mankind, guard against the disturbance of the resting place of the dead, which would naturally ensue if the ground was liable to be sold to enforce the collection of taxes or assessments." See Colston v. Cemetery Co. (Ky.), is S. W. Rep. 245. There are undoubtedly a number of cases like that in Illinois in which the plain and obvious meaning of an enactment has been construed away. But many of them, as shown above, even those which hold the word "taxation" in a general statute, not to include municipal assessments, have given weight to the meaning of the legislature, when it was at all clearly apparent. In Pennsylvania, prior to the constitution of 1874 , it had expressly been held that such assessments were taxes and could be nothing else. The Act of 1874 exempts " from all and every county, city and borough, road, school and poor tax." It was passed May I4, I874. It is of one section, and is a special exemption Act-not part of general law authorizing taxation. It shows, as to charitable and religious institutions, a desire to exempt only those which are strictly and purely public charities-and only such of their property as . is in actual occupation-and these institutions it includes with "court house, jails," in the exemption above. "All and every" would seem to be a complete and thorough exemption -and coupled with the fact that a road tax-a special tax on the surrounding property for a special expenditure-so levied because it is supposed that the immediate locality will be chiefly 
benefitted-is included in the provisions of the Act, would seem to make the meaning of the legislature too clear for argument. It is true a road tax is not levied by the frontfoot rule-but it is the same in general principle. In addition to this, as before noticed, "tax" included municipal assessments, according to the law as it stood when the Act was passed. Now, let us return for a moment to Eric r. The Church, ro5 $\mathrm{Pa} .278$. Here we find some of these arguments recognized, and we are truly told by the court (GoRDon, J.), that "the Act speaks in no doubtful terms concerning the exemption of this kind of property from every variety of city tax," and that, as every one knows, that jails and court houses are not intended to be taxed at all, churches, etc., being classed with them, are also free-either both are free, or neither is free-and "if this is not the true meaning of the Act, I confess my inability to understand it."

But all this may be considered, perhaps, beside the mark. The court expressly overrules its former decisions, and it may, therefore, be useless to quote them. It will not, I think, however, be obvious to the profession that consonancy with decisions of other states, in a matter of internal policy like this, was important, or even desirable. It is implied in the tenacious clinging to local self-goverment that different localities may and will desire different laws. And it can hardly be said that the desired consonancy is secured-for it will be difficult to show that the weight of authority would construe such a statute in this way. Statutes are to be construed according to the piain meaning of their words, unless there be some strong reason to suppose that they are intended to have some unusual meaning-this is a well recognized rule of construction, and it is another well-known rule that a State Legislature is free to pass any laws not prolibited by the constitution-it does not, therefore, depend for its right to pass exemption laws upon any constitutional grant. See Am. Encyc. Law, Vol. 25, p. 156. And this does not seem to be questioned elsewhere. The effect of the decision will be to go down deeper into the pockets of those who have established charities and churches -and who by so doing have performed a noble public service. 
It is not worth while to argue so plain a proposition as that both charities and churches save the community from terrible charges and evils-and an uncalled for check to the altruistic spirit of those who have some care for their fellow men must be deplored, as it seems to me, as retrogression. It will not do to push these considerations aside as mere sentimentalism. Some years ago the late venerated Judge Sharswood declared that Christianity was part of the common law of Pennsylvania; and if she is alone in her policy, it is a position in advance, not in the rear. Why change, when even the pecuniary gain to the treasury of any municipality would be inconsiderable-scarcely appreciable by the tax-payers-and yet the burden upon deserving charities would be very severe? Tempora mutantur-et nos mutamur in illis-six long years have rolled around since the court expressed its regret that it could not relieve a home for aged women, even of the duty of repairing a sidewalk; and its views have completely changed. Many, however, who agreed with court in its regret, are of the same opinion still. I intend, I need hardly say, no disrespect to the court, and, as Judge Woodward said, in the Conscript Cases, I must be understood as conceding to others the freedom of opinion and rectitude of purpose, I claim for myself-and in this spirit it is that I add, with him, "God save the commonwealth if such a precedent is to be established!"

LuCIUS S. LANDRETH. 